\title{
Updating the internal structure of living space for arctic conditions
}

\author{
Aleksey Tokarev ${ }^{1, *}$ \\ ${ }^{1}$ Tyumen industrial University, Volodarsky, 38, Tyumen, 625000, Russia
}

\begin{abstract}
The purpose of this study is to draw attention to the environmental problems of active development of the Arctic territories and to determine the specification of the necessary functional zones and conditions of comfortable living space for the harsh Arctic conditions. The study summarized the problems and threats of specially protected natural areas - the "Russian Arctic" national park. The aspects for modern town planning in extreme conditions of high latitudes are concretized during the process of analyzing historical examples of the formation of "Ideal cities", conceptual projects of "Cities of the future". The essential town planning and spatial-planning miscalculations of existing shift villages of the North of Russia are revealed. The requirements to modern Arctic architecture for comfortable living in the conditions of the Far North are grouped and defined. As a result of the study, the actual composition of the main, auxiliary and technical premises necessary for the life activity of the Arctic module of temporary residence of the XXI century is presented. The value of the results lies in the formation of the necessary requirements for designing of a comfortable living space in Arctic conditions and the real possibility of using principles of functional structuring for the creation of space-planning, ecologically balanced environment of stand-alone module of temporary residence on the specially protected territory of "Russian Arctic" national park.
\end{abstract}

\section{Introduction}

Nowadays, we are witnessing that the Arctic evolution program is supported at different state levels in many countries [1, 2, 3, 4]. Not only Russia, but also neighboring States are interested in the development of the Arctic [5, 6, 7]. For example, the Norwegian cruise company "Hurtigruten" intends to develop tourism to the Arctic and in the coming years to create conditions for regulated tourism and recreation $[8,9]$.

The relevance of this problem can be clearly seen in the materials of plural conferences, such as: "Actual problems of architecture, civil construction and environmental economics" (TPACEE 2018), held in Moscow, Russia, December 3-5, 2018 and XXII International scientific conference "Formation of habitat" (FORM-2019) Tashkent, Uzbekistan, April 1821, 2019. The problem of development of new and reconstruction of existing infrastructure in the Arctic includes not only social and economic, technological and planning

\footnotetext{
*Corresponding author: aetokarev65@gmail.com
} 
components, but, in fact, any development requires consideration of extreme climatic conditions that affect the concept and operation of cities $[10,11,12]$. The ideas that define the unique typology of urban and architectural design in the conditions of extreme Northern climate were expressed by Matthew Jull in 2016 in the paper "On the way to Northern architecture: the neighborhood as an Arctic urban prototype" [13].

It should also be noted that in 2011, the Order No 806 of the Ministry of natural resources and ecology of the Russian Federation dated 04.10.2011 "On establishing the regime of protection and use of the protected Arctic zone" was issued. This order defined the structure of administrative and territorial division of the specially protected natural area "SPNA": national Park "Russian Arctic" which includes: marine and coastal areas; NorthWestern Federal district; Arkhangelsk region. The total area of SPNA was: 1426000.0 hectares; the area of marine specially protected water area: 793910.0 ha; the area of land included in the boundaries of SPNA without withdrawal from economic use: 1426000.0 ha.

The main tasks of creation of SPNA are also important for our research:

- preservation of natural complexes, unique and reference natural sites and objects;

- preservation of historical and cultural objects;

- environmental education of the population;

- development and implementation of scientific methods of nature protection and environmental education;

- implementation of environmental monitoring;

- restoration of disturbed natural and historical-cultural complexes and objects $[14,15]$.

At the same time, it is necessary to emphasize the ecological problem of the national Park "Russian Arctic", which consists in a partial coincidence of the Park and the Yamal reserve with license areas for oil and gas production. The current situation is reflected in the interactive map of all Federal specially protected natural areas of the Russian Arctic, prepared by Greenpeace Russia (Figure 1).

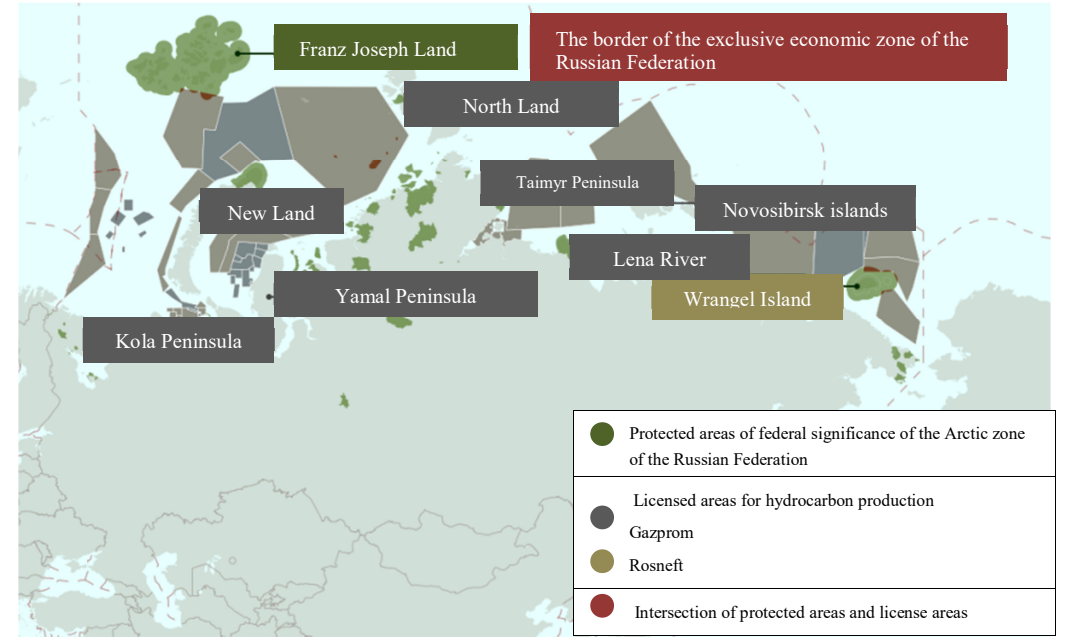

Fig. 1. Map of Federal specially protected natural areas of the Russian Arctic and license areas for oil and gas production. (http://www.greenpeace.org/russia/ru/campaigns/protect-the-arctic/threat-to-the-Arctic)

The purpose of this study was to formulate and systematize the basic requirements for the modern architecture of the residential Arctic module, to present a list of functional areas and its constituent main and auxiliary premises. 


\section{Materials and Methods}

\subsection{Major environmental problems and threats}

Throughout our research process, we used general, basic methods of scientific knowledge: empirical and theoretical. The Arctic has always been a territory of attraction for enthusiasts-pioneers, passionate about research activities. Now, in the era of globalization, it is a very delicate ecological system with specific natural and geographical features and its problems are no longer regional. Let's list the main, real-life problems:

- Unauthorized presence and waste of human activity lead to melting of Arctic ice and, as a consequence, to climate change;

- Pollution of the Arctic ocean seas by runoff of petroleum products and chemical compounds, spills from oil production;

- Increase in Maritime transit;

- Irreparable damage to flora and fauna is caused by the presence of oil in the water and on land. Settling on the feathers and skin of animals, oil deprives them of protection from the cold, prevents flying;

- Pollutants at low temperatures for a long time retain a negative impact on human health;

- Illegal extraction of valuable species of fish, low control over the issuance of licenses for the extraction of animals;

- Presence of dangerous animal burial grounds.

Historically, the urban environment was formed under the influence of territorial and climatic features, while solving social and economic, religious and political problems of society.

\subsection{Paradigm of formation of "the cities of the past"}

To achieve our goal, we consider it appropriate to analyze the projects and developments of ancient town planning. Turning to the works of the greatest architects and scientists, we noted the most consonant with the assigned tasks and identified the most valuable parameters for our project. The following works were selected:

1. The city-the street of XIV-XVI century by the Architect Leonardo da Vinci.

2. The ideal city XVI century. Architect: Fra Giocondo.

3. Garden City 1898 Architect: E. Howard

4. Sforzinda-star city Renaissance 1465 Architect: Antonio Filarete.

5. Amaurotum-the ideal city 1512 Architect: Thomas More.

6. Round city-Ikaria 1840 Architect: E. Cabet

7. City Chaux. XVIII century. Architect: Claude-Nicolas Ledoux.

8. The linear city. The idea of the late 20 s early 30 s years.

9. Ladovsky Parabola.

A number of structural and functional parameters were identified in each project. The parameters of "Ideal cities" are presented in the table 1: 
Table 1. The parameters of "the Ideal Cities"

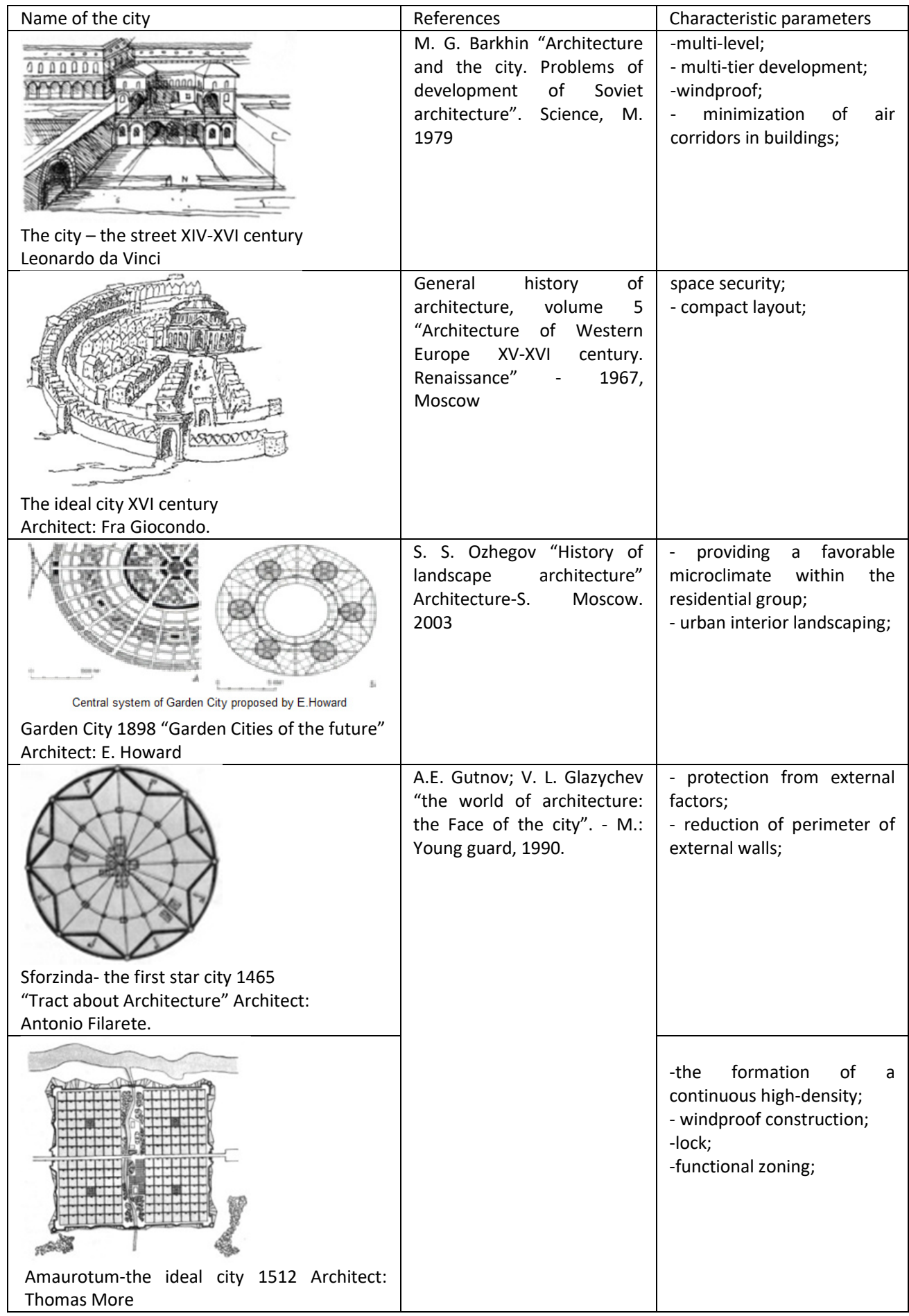




\begin{tabular}{|c|c|c|}
\hline 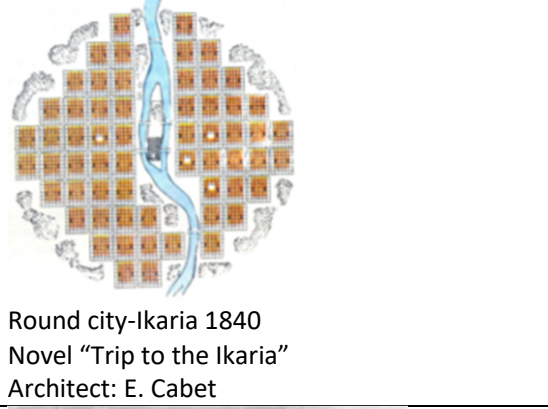 & & $\begin{array}{l}\text { - intuitive orientation; } \\
\text { - the presence of a public } \\
\text { area near the water; } \\
\text { - providing access to any } \\
\text { settlement facility; }\end{array}$ \\
\hline 20 & $\begin{array}{l}\text { "Claude-Nicolas Ledoux. } \\
\text { Architecture considered in } \\
\text { relation to art, manners and } \\
\text { legislation". } \\
\text { A. A. Barabanov. Publishing } \\
\text { house "Arkhitekton". }\end{array}$ & $\begin{array}{lcl}- & \text { interpenetration } \\
\text { settlement and nature; } & \end{array}$ \\
\hline $\begin{array}{l}\text { The linear city. The concept of a linear city } \\
\text { emerged as a counterbalance to the ideas of } \\
\text { ultra-compressed compact cities and total } \\
\text { urbanization. } \\
\text { The Concept revived the village buildings. }\end{array}$ & $\begin{array}{l}\text { A. V. Bunin, } \\
\text { T. F. Savarenskaya. } \\
\text { "Town planning of the XX } \\
\text { century in the countries of } \\
\text { the capitalist world". } 1979 \text {. } \\
\text { Volume two. }\end{array}$ & $\begin{array}{l}\text { - selection of the site for } \\
\text { construction taking into } \\
\text { account natural and climatic } \\
\text { features; }\end{array}$ \\
\hline $\begin{array}{l}\text { Ladovsky Parabola. } \\
\text { With the radial-ring structure of the city, the } \\
\text { rings are layered on top of each other creating } \\
\text { chaos. Ladovsky breaks the rings and opens } \\
\text { Moscow in the direction of Leningrad. Town } \\
\text { planning will turn into a comet with a head in } \\
\text { the historical center. }\end{array}$ & & $\begin{array}{l}\text { - unified architectural and } \\
\text { planning concept of } \\
\text { building; }\end{array}$ \\
\hline
\end{tabular}

Thus, we have identified general principles for the forming of "Ideal city" of the middle ages and Renaissance: - a closed or partially open to nature territory, and only since the development of architectural modernism and functionalism of the XX century, the city was free to interpret its functional beginning and the possibility of zonal resettlement. It seems that these updated parameters: multi-tiered building; compact layout; providing a favorable 
microclimate; internal landscaping; protection from external factors; wind protection of buildings; wind regime of the territory; the presence of public areas; the choice of the site taking into account natural and climatic features; the unified architectural and planning concept of the building should be reflected in the structure of the basic requirements for the modern architecture of the Arctic modules of temporary residence [16, 17].

\subsection{Fundamental principles of "Cities of the future"}

The current state of the planet, the priority and most important tasks in the design of urban space, determines the environmental principles of town planning. From created, with maximum use of modern possibilities of architectural design of images of "Cities of the future", we have stopped the choice on those which in our opinion formulate parameters significant for our research. We believe that in order to form the fundamental requirements for residential Arctic architecture, it is also necessary to analyze innovative conceptual projects of the new Millennium. Let's focus on six projects of modern architects and designers:

1. "The world" Bureau "Elis" Director Nikolai Lyutomsky.

2. "Eco-resort" in Liwa. architect Bacharach.

3. "Floating green" Japan.

4. Havvada island, Dror Benshetrit Studio.

5. Underwater city "Aequorea", architect Vincent Callebaut.

6. City in the sky "City of lotuses", architect Tsvetan Toshkov.

Each project emphasizes from the set, it is the environmental parameter. The parameters of "Cities of the future" are presented in the below table 2 .

Table 2. Projects of "Cities of the future". A full description of the projects can be found on the Internet.

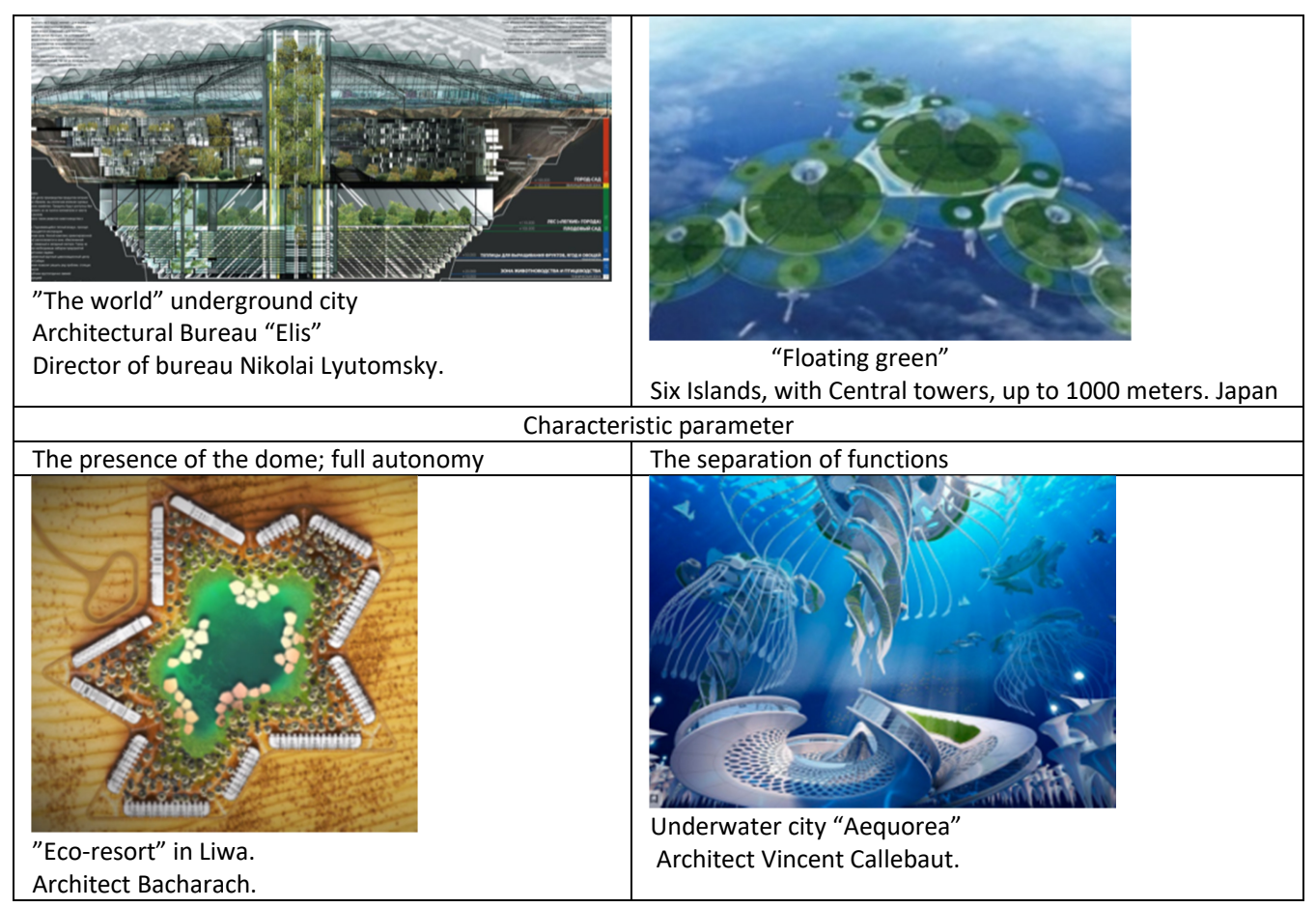




\begin{tabular}{|l|l|}
\hline & \multicolumn{2}{c|}{ Characteristic parameter } \\
\hline Interior landscaping & Building materials \\
\hline & \\
\hline $\begin{array}{l}\text { Havvada island } \\
\text { Dror Benshetrit Studio }\end{array}$ & $\begin{array}{l}\text { City in the sky - "City of lotuses" } \\
\text { Architect Tsvetan Toshkov }\end{array}$ \\
\hline Simplicity of forms & Interior landscaping \\
\hline
\end{tabular}

Thus, these projects simultaneously reflect not only social, economic and industrial problems, but also consider the organization of urban public spaces, and most importantly, the environmental problems of total pollution and disrespect, loss of understanding with nature are put at the "forefront". Let's list the important parameters for our zoned space: the presence of a dome; full autonomy; climate-saving qualities of buildings; interior landscaping; separation of functions; simplicity of forms; construction materials from garbage, using 3D printing; reproduction of food products $[18,19]$. At the same time, some of the identified parameters were realized by the Belgian Antarctic station Princess Elisabeth Antarctica, located to the North of the Viking Height of Queen Maud Land. Figure 2.

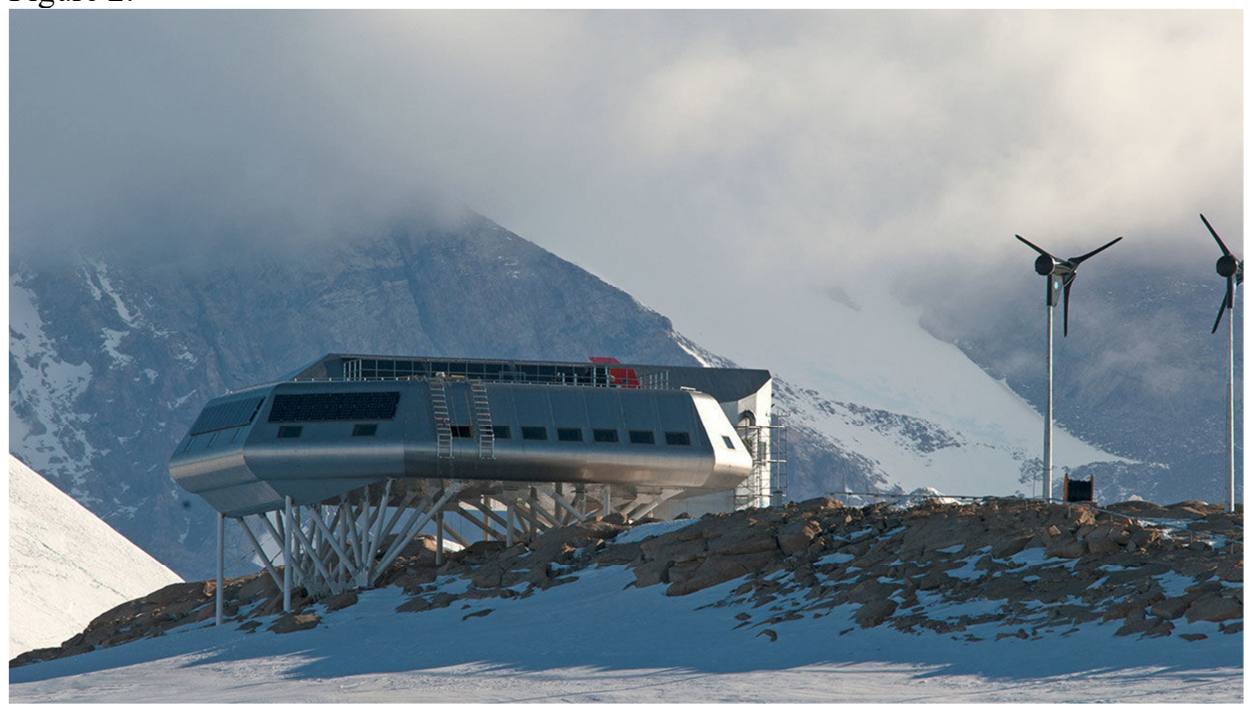

Fig. 2. The Belgian Antarctic station Princess Elisabeth Antarctica. A full description can be found in the Internet.

The station is an architectural and technological work of Belgian Alain Hubert. Architect Philippe Samyn. The base began its operation in February 2009. The characteristic parameters of the station: "zero emissions", no waste and emissions into atmosphere; using environmentally friendly building materials; use of clean energy of wind turbines and solar cells; optimization of energy consumption; eco-friendly waste management. It is designed for accommodation of 16 scientists. More information can be found on the official website http://www.antarcticstation.org. 
Continuing the study, it is advisable to mention the search for other alternative conceptual developments, the further development of the earth's civilization [20]. One of them is resource-oriented economy. So on the official website of the movement "Designing of the future" declared 18 goals of "Project Venus". Let us list some, in particular relating to the conservation and careful development of SPNA of the Russian Arctic:

1. The planet's natural resources belong to humanity;

2. Systematic renewal of these resources;

3. Modern technological advances are at the service of humanity;

4. Use of natural energy;

5. Production of high quality food;

6. Expertise of construction projects on the environmental effect already in operation process;

7. To provide humanity with the opportunity to solve not only utilitarian tasks, but also highly intellectual;

8. Comprehensive preparation of people for a new way of life.

\subsection{A study of residential areas of shift villages}

We should not forget about the possible reconstruction of the existing villages of shift workers. We stopped at six shift villages: Yamburg; Sabetta; Northern Danilovka; Lovinka; Pionerny and Bovanenkovskoye oil and gas condensate field. Geographically located in the North of the Tyumen region (figure 3 ).

We analyzed all available project documentation. The scheme of planning organization of the territory of villages with the use of ArchiCAD software is recreated. When discussing the classical principles of town planning, namely: natural-climatic, spaceplanning, structural, engineering, economic, social, we have identified certain shortcomings in ensuring the comfort of living, in terms of energy efficiency of building. The results of the analysis and a brief description of the geographical location of the villages are shown in table 3.

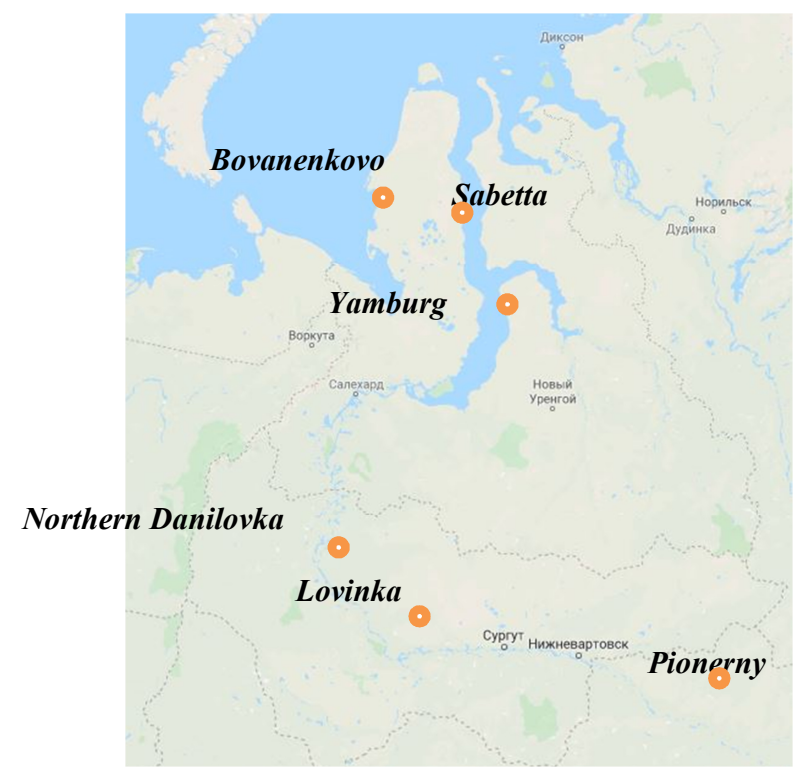

Fig. 3. Schematic map of the Tyumen region. Territories of Khanty-Mansiysk and Yamalo-Nenets Autonomous regions. 
Table 3. The results of the analysis of the geographical position of the existing shift villages.

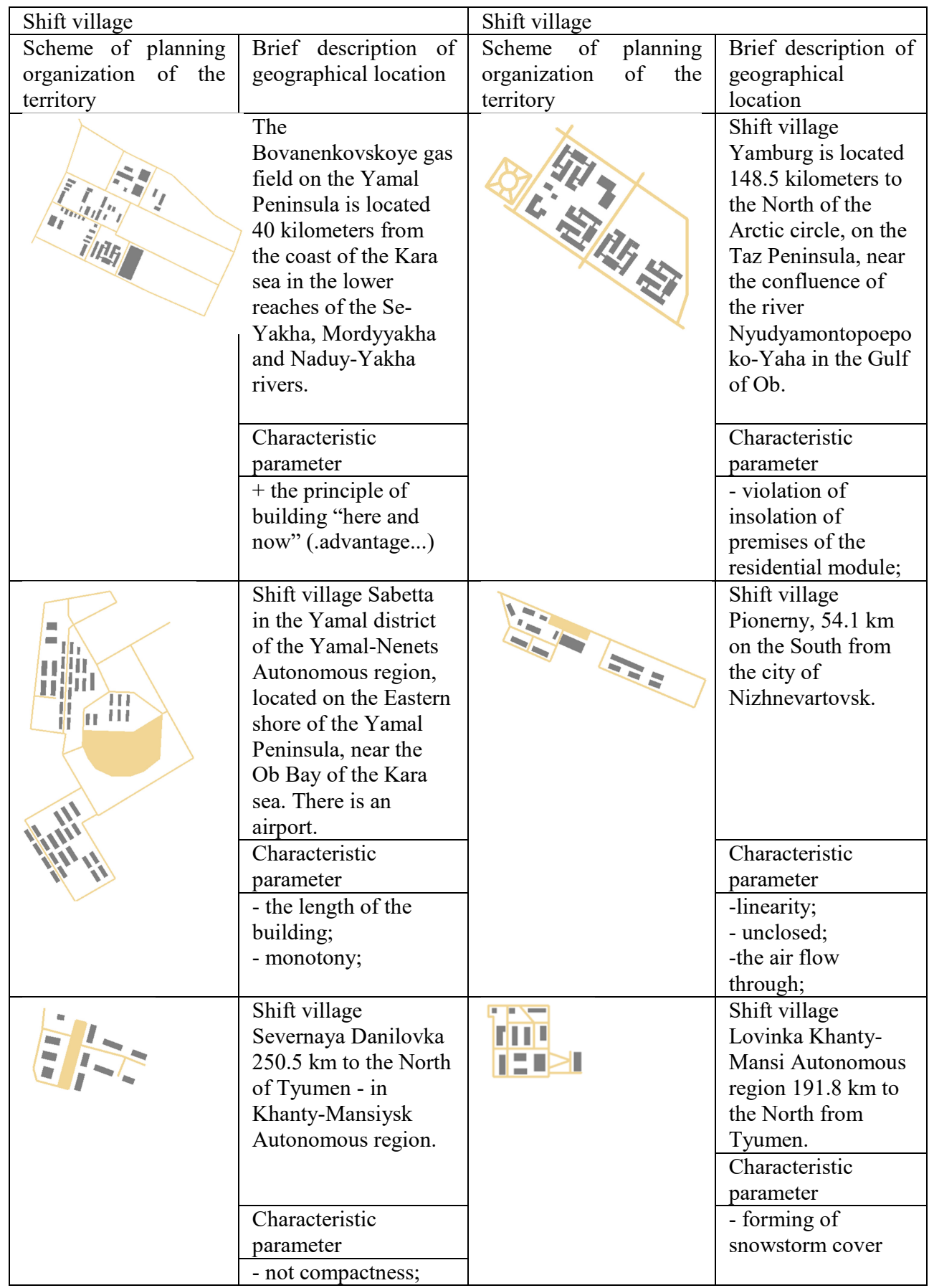

Thus, as a result of the analysis of all situational schemes, it can be concluded that all planning villages to a greater or lesser extent meet the requirements of town development. At the same time, it is necessary to carry to lacks of energy efficiency of building: extent and monotony of building; violation of insolation of premises; not compactness; possibility of formation of snowstorm covers; straightness; unclosed; blowability. 
Apart is the shift village of Yamburg, built up with residential modules of the Finnish production of the last century, where there is a dining room, gyms, TV room, billiard room, library, everything you need for life without going outside.

The infrastructure of the Bovanenkovo oil and gas condensate field is also interesting, today it consists of modern youth centers, polyclinics, shopping and concert halls, sports complexes. And with the commissioning of the third gas field on December 5, 2018, the requirements for the comfort of construction grow to the urban level.

In the process of searching and analyzing the literature that sets standards, the question arose: "What architectural measures in cooperation with the Order of the Ministry of natural resources and ecology of the Russian Federation from 04.10.2011 No 806 will be able to establish a regime of protection and use of the created SPNA national Park "Russian Arctic"? At the moment there are only a few legal and regulatory documents: "Town planning code of the Russian Federation" from 29.12.2004 No 190-FZ (ed. from 25.12.2018); Standards of town planning design of the Irkutsk region from 08.08.2018 No 02-82-682 /18.; SP 31-107-2004. Architectural and planning solutions of multi-apartment residential buildings.

Earlier in our study, we mentioned the actual environmental problems and threats of SPNA in the Arctic. In this regard, we consider it necessary to list the objects primarily subject to protection. These include:

- Landscapes of polar deserts and Arctic tundra with extensive glacial covers;

- Flora of the high Arctic and Arctic tundra, characteristic plants: polar poppy, saxifrage, grits, polar willow, etc.;

- Places of concentration of valuable and rare species of animals, important habitats of the polar bear, rookeries of the Atlantic walrus, habitats of the new earth reindeer, the Atlantic black Cossack;

- Large colonies of seabirds, including the most northeastern nesting sites of the Atlantic thick-billed Kaira;

- Historical and memorable places associated with sea voyages, expeditions of Arctic explorers, research of the Soviet period;

- The most significant object of international importance is the complex of monuments of the Dutch expedition of Willem Barentsz.

\section{$3 \quad$ Results}

\subsection{Current requirements for modern architecture of living space for the Arctic}

Thus, the study revealed a number of structural and functional parameters of "Ideal cities". The parameters of conceptual projects of "Cities of the future", which are significant for our analysis, are established. Shortcomings and shortcomings in energy efficiency of building of existing residential territories of shift villages are noted. Also, the existing (Belgian Antarctic station Princess Elisabeth Antarctica) and alternative projects for the development of Arctic territories were considered.

As a result of the analysis we were able to formulate and systematize the following fundamental requirements for modern residential architecture for the Far North:

1. Town planning:

- selection of the site for construction taking into account natural and climatic features;

- providing a favorable microclimate within the residential group;

- no blowing and minimization of air corridors in the building; 
- the formation of a continuous high-density windproof building;

- blocking buildings;

- providing the required insolation of the territory and premises;

- necessary and sufficient lighting of the territory;

- providing access to any settlement facility;

2. Space-planning:

- unified architectural and planning concept of building;

- compact layout and volume-shaped solutions of the building;

- availability of public communication area;

- maximum increase in the width of the housing;

- reduction of perimeter of external walls;

- use of the block section of meridional, latitude, free orientation and angular, rotary, windproof;

- ensuring the stability of the room temperature regardless of weather conditions;

3. Constructive:

- selection of the optimal structural system and scheme of the building;

- high degree of factory readiness of the foundation of individual elements;

- use of prefabricated modular structures;

- application of modern multilayer enclosing structures;

- ensuring minimum windage of structures;

- the use of flammable building materials;

- the use of high-performance insulation [21];

- use of modern facing materials;

- placement and optimal dimensions of translucent elements;

- application of spatial shell;

4. Engineering:

- application of technologies that protect the human environment from adverse atmospheric phenomena;

- use of renewable resources: solar cells, wind generators [22, 23];

- ensuring the circulation of domestic consumption and production (autonomous biosystems);

5. Social:

- in addition to the design of utilitarian premises, special functional premises are needed: to maintain the physical health of people; to create a healthy psychological microclimate in a monotonous landscape; to develop creative abilities; to organize out-of-hours rest; to create a psycho-emotional "refuge" for relaxation;

6. Health parameters according to the WELL standard:

- air; - water; - food; - lighting; - fitness; - comfort; - psyche.

Specific requirements to the modern architecture of Arctic settlements are formulated, it is possible to propose a new composition of premises necessary for the life of the Arctic research module, perhaps even a tourist center [24].

The following is a list of functional areas and their constituent main and auxiliary facilities and equipment:

1. Elements of the zone of Autonomous life support system of a residential complex developed by LLC "Science and production company TGM".

1.1 life support system: low temperature heat accumulator; high temperature heat accumulator.

1.2 Zone of alternative energy sources.

1.3 waste treatment unit: machine room; regenerative heat exchanger; solar cells; thermal energy recovery system; wind farm; wind farm in the rotary unit. 
2. Transport terminal:

2.1 Zone of external transport infrastructure; for meeting visitors; luggage accommodation;

2.2 The block - zone of household service of the workers returning from shift.

3. Zone of engineering infrastructure: placement of engineering equipment; engineering networks and communications.

4. Utility and storage area:

4.1 Economic zone: vegetable base; reception area of household goods; food; equipment; warehouse premises;

4.2 Area of production and storage of agricultural products;

4.3 Area of production and storage of livestock products.

5. Zone of technical and electronic support of the complex: transformer station; server.

6. Research area: lecture hall; various laboratories for scientific research; experimental laboratories; storage; training unit with a universal hall and classrooms; sanitary facilities; staff room.

7. Administrative and commercial zone.

7.1 meeting area and accommodation of visitors: administrative block: reception; waiting room reception; staff room; sanitary facilities.

7.2 Public and business area: Internet cafe; gift shop; open area for various actions.

8. Health zone: medical and preventive center; first-aid post; waiting room; temporary detention ward; medical offices: therapist; dentist; otolaryngologist; surgical room; dressing room; sanitary units; staff room.

9. Zone of cultural objects: theater and entertainment space, including the auditorium and stage; museum; art cafe; photo studio.

10. Cult zone: cultural and educational activities of various faiths.

11. Communication facilities: corridors; elevators; stairs; horizontal the moving walkways; technical blocks with elevators.

12. The block of consumer services: waiting room; sanitary units; service points: laundry; ironing room; room of the matron.

13. Zone of accommodation facilities for workers and staff:

- standard room "A": room I category, consisting of one living room with one or two beds, with a full bathroom (shower, sink, toilet), designed to accommodate one or two people.

- standard room "B": a room of category III, consisting of one living room with the number of beds according to the number of residents, with one full bathroom in a block of two or three rooms, designed to accommodate several people;

- round-the-clock dining room;

- kitchen.

14. Zone of temporary accommodation facilities for tourists, researchers, guests:

- "Junior suite" - a one living room with an area of at least $25 \mathrm{~m}^{2}$, designed for one or two people with a layout that allows you to use part of the room as a living room or dining room, or office.

- "Lux" - a room of at least $35 \mathrm{~m}^{2}$, consisting of two living rooms: lounge and bedroom, designed for one or two people.

- Service area: bar; restaurant; kitchen.

15. Zone of temporary accommodation facilities of honored guests:

- "Suite" - a room of at least $75 \mathrm{~m}^{2}$, consisting of living rooms: lounge, dining room, study and bedroom with a non-standard double bed and an additional guest toilet.

16. Area guests of honor: the congress hall with a private elevator and a kitchen; playground with a panoramic view of the "ball". 
17. Landscaping area: indoor closed: organized on the principle of through landscaping; landscaping stairs; private areas; two-light spaces; atrium space; galleries; corridors; winter gardens in residential areas; lawns for walks and quiet rest.

18. Sports and recreation complex:

18.1 Active recreation area: gym; swimming pool; changing rooms; showers; sanitary facilities; steam room; recreation room.

18.2 Play area: universal multifunctional play area for mini football; basketball; volleyball; recreational outdoor area for winter recreation; summer recreation area.

18.3 Passive recreation area: recreational area of communication and recreation; billiard room; game room; warehouse; staff room; sanitary facilities; creative laboratories; zone of unorganized walks; free rest; green recreation area near the water.

From the above we can conclude that the lack of energy efficiency of small villages is explained by certain difficulties of construction, the lack of modern technologies. For example, it is not paid worthy attention to the difficulties of transport accessibility from places of residence to the place of employment - "the workplace of the shift worker". In addition, there is no waiting terminal for specialized transport for the delivery of workers. It is necessary to avoid the shortcomings noted in the formulation of the basic requirements for the modern architecture of temporary Arctic settlements.

\section{Discussion}

On the basis of the obtained results, it can be concluded that it is necessary to formulate specific architectural, planning and town planning requirements for the modern architecture of Arctic settlements, in order to create a conceptual model of an isolated multifunctional module of temporary residence, or even a mobile military camp.

It should be noted that the creation of a conceptual model of the spatial environment of the temporary residence module for the far North is radically different from the traditional design of the shift village. We consider it necessary to consider the residential module from the perspective of a modern residential area of the city. When creating an architectural solution, take into account energy efficiency and environmental friendliness of the building design $[25,26]$.

For a starting point, in search of a figurative solution, it can be taken a medieval fortress city with a donjon tower, which corresponds to a closed autonomous system of life support and food. It is advisable to use a dome that reflects and retains heat, prevents the effects of global warming, creating a closed, isolated from external influences living space. On the one hand, the space does not harm the environment, on the other hand, the internal living environment is functionally zoned and harmonious in interaction with nature. Also, it is advisable to have a cargo and passenger transport terminal for:

- distribution of cargo and passenger flows;

- providing access to rolling stock;

- implementation of the main transport between the terminals with vehicles of maximum performance;

- change of rolling stock if necessary;

- servicing passenger flows as the main transport hub.

Having traced the main parameters of design - environmental and energy-efficient aspects, we assume that they are decisive in matters of resource conservation. 


\section{Conclusions}

Based on the results and subsequent discussion, it can be concluded that the temporary residence modules created in the process of architectural creativity on the basis of functional zoning of premises will contribute to the further environmental development of the SPNA of the national Park "Russian Arctic".

\section{References}

1. HR1146: the Law regarding Arctic crops and coastal plains, the Text of the law draft as of September 12, 2019 has been submitted to the U.S. Senate Committee. (2019)

2. The Arctic portal. Arctic development, in theory and in practice Akureyri, Iceland. (https://issuu.com/arcticportal/docs/arctic_yearbook_2018; Arctic Yearbook 2018.) (2018).

3. The Inuit circumpolar Council (ICC). Canada. http://www.inuitcircumpolar.com/

4. M. A. Xinmin, Maritime policy Volume 100, 265-276, (2019)

5. N. Andreassen, Energy and social science research Volume 16, 78-88 (2016)

6. J.R. Berthelsen, V. Gallucci, Maritime policy, Volume 72, 240-245 (2016)

7. Hyun Jung Kim. Maritime policy, Volume 61, 264-272 (2015)

8. M. Hansen, Y. Falk-Andersson, G. Kofi Vondolia, T. Borkh, D. Tinch. Oceans and coastal management, Volume 153, 157-167 (2015)

9. J.S. Chen, Ya-Lin Chen Magazine of outdoor activities and tourism, Volume 16 Pages 1-6 (2016)

10. I. Dunichkin, C. Bleil de Souza, et al., E3S Web Conferences, volume 97,01036 (2019)

11. L. Johannsdottir, D. Cook Oceans and coastal management, Volume 179 ,104853 (2019)

12. M. Farish and P. Whitney Lackenbauer, Journal of historical geography, Volume 35, Issue 3, 517-544 (2009)

13. C. B. Swap, D. Hernandez. Social Sciences and medicine volume n.a., 112571, (2019)

14. M. Kanao, V. Suvorov et al., Boundaries of Geoscience Volume 6, Issue 5, 665-677 (2015)

15. D. W. Hausknecht Sedimentary basins of the United States and Canada 719-745 (2019)

16. Y. Gribach, O. Poddaeva, P. Churin, E3S Web Conferences, volume 91, id. 05022 (2019)

17. N. Kishore Khambadkone, R. Jain. Construction and environment Volume 123, 469493 (2017)

18. M. Eichner, Z. Ivanova E3S Web Conferences, volume 91, 05015 (2019)

19. M. van den Berg, W. Wendel-Vos et al., Urban forestry and urban greening, Volume 14, Issue 4, 806-816 (2015)

20. F. Blomsma, Journal of clean production, Volume 199, 969-982 (2018)

21. D. Pride, J. Little, M. Mueller-Stoffels, Energy policy, Volume 123, 450-460 (2018)

22. P. Lundqvist, M. Risberg, L. Westerlund, Construction and environment, Volume 160, 106164, 2019

23. H. Yoshino, R. Takaki, et al., Solar energy, Volume 105, 243-263, 2014

24. S. Hirvonen-Kantola, P. Ahokangas et al., Geography Economics and Finance, Volume 21, 337-345, 2015

25. F. Perov, A. Eremeeva, S. Shabiev, E3S Web Conferences, volume 91, 05025 (2019)

26. J.G. Sutinen, C.L. Dyer et al., Large marine ecosystems, Volume 13, $27-81$ (2005) 